Check for updates

Cite this: RSC Adv., 2020, 10, 33334

Received 4th June 2020

Accepted 20th August 2020

DOI: $10.1039 / \mathrm{dOra04925e}$

rsc.li/rsc-advances

\section{Chitosan-encapsulated manganese ferrite particles bearing sulfonic acid group catalyzed efficient synthesis of spiro indenoquinoxalines $\uparrow$}

\begin{abstract}
Sepideh Lahouti and Hossein Naeimi iD *
A simple, highly versatile and efficient synthesis of 5-phenyl-spiro[diindenopyridine-indenoquinoxaline]diones is achieved through a four-component one pot reaction of ninhydrin, 1,2-diaminobenzene, 1,3indandione and aniline. This reaction was catalyzed by $\mathrm{MnFe}_{2} \mathrm{O}_{4} \mathrm{aCS}-\mathrm{Bu}-\mathrm{SO}_{3} \mathrm{H}$ MNPs as a very efficient, recyclable heterogeneous catalyst in acetonitrile under reflux conditions. The catalyst can be recovered from the subsequent reaction mixture and reused for at least five cycles without any appreciable loss in its efficiency. The core-shell structure and composition of the produced magnetic nanocatalyst were analyzed using FT-IR, XRD, VSM, SEM, EDX and TGA techniques.
\end{abstract}

\section{Introduction}

Spirocycles, structures that have two or more rings joined at a single carbon, remain a challenging design for synthetic chemists. Some of the most important spirocycles are spirooxindole and spiroindoline alkaloids isolated from natural sources. ${ }^{1-3}$ Spiropyrans and spiroquinoxalines, in particular, have possible applications as photochromic materials in data recording, storage, and transfer and in other industrial fields. ${ }^{4}$ The indole nucleus is perhaps the most well-known heterocycle, a common and important feature of a variety of natural products and medicinal agents. ${ }^{5}$ The spirooxindole ring system is a broadly dispersed structural framework present in a number of natural and pharmaceutical products. Indenoquinoxaline derivatives are an important class of nitrogen-containing heterocycles which are useful intermediates in organic synthesis. ${ }^{6,7}$

Heterogeneous catalysis has been studied for many years and has become vital for efficient and eco-friendly organic transformations over the past few decades..$^{8-10}$ Magnetite is an ideal oxide support and easy to make, with a very effective surface for adsorptions or immobilization of metals and ligands, which can be separated by magnetic separation. ${ }^{11}$ Magnetite nanoparticles are not very resistant under ambient conditions and are easily oxidized to magnetite or dissolved in an acidic medium. ${ }^{12}$

Chitosan (CS) has various favorable properties, such as, biocompatibility, low toxicity, good film making, high mechanical strength and high hydrophilicity, and has therefore been an important material for the preparation of magnetic carriers.

Department of Organic Chemistry, Faculty of Chemistry, University of Kashan, Kashan, Iran.E-mail: naeimi@kashanu.ac.ir; Fax: +98 591 2397; Tel: +98 5912388

$\dagger$ Electronic supplementary information (ESI) available. See DOI: 10.1039/d0ra04925e
Chitosan is a natural attractive due to the presence of amine and hydroxyl groups. ${ }^{13-16}$ These groups serve as adsorption sites for many adsorbates. Therefore, it is an appropriate polymer for use to modify $\mathrm{MnFe}_{2} \mathrm{O}_{4}$ NPs. Many investigations have been performed on chitosan-modified magnetic NPs for biomedical applications. ${ }^{\mathbf{1 7}}$

Multicomponent reactions (MCRs) enjoy an outstanding reputation in organic and medicinal chemistry for their high degree of atomic economy and application in the diversity oriented convergent synthesis of complex organic molecules from simple and readily available layers in a single vessel; they fulfil some of the objectives of perfect synthesis because complex products are formed in a single step and diversity can be obtained simply by varying the reaction components. ${ }^{18-24}$

In continuation of our previously reported work on catalytic reactions, ${ }^{25,26}$ herein we report the preparation of $\mathrm{MnFe}_{2} \mathrm{O}_{4} @ \mathrm{CS}$ $n$-Bu-SO $\mathrm{SO}_{3} \mathrm{H}$ MNS and their use as an efficient nanocatalyst for the synthesis of 5-phenyl-spiro[diindenopyridineindenoquinoxaline]-dione derivatives through the condensation of ninhydrin, 1,2-diamino-benzene, 1,3-indandione and various anilines under thermal conditions (Scheme 1).

\section{Results and discussion}

2.1. Preparation and characterization of $\mathrm{MnFe}_{2} \mathrm{O}_{4} @ \mathrm{CS}-\mathrm{Bu}$ $\mathrm{SO}_{3} \mathrm{H}$ MNPs

The manganese ferrite nanoparticles were prepared by coprecipitation of $\mathrm{Fe}(\mathrm{III})$ and $\mathrm{Mn}$ (II) at a molar ratio of $2: 1$ which was dropped slowly into $\mathrm{NaOH}$ solution at a temperature of $97{ }^{\circ} \mathrm{C}$. Then, the synthesized magnetic nanoparticles were modified with chitosan as a natural polymer. To prepare the modified $\mathrm{MnFe}_{2} \mathrm{O}_{4}$-chitosan nanoparticles, $\mathrm{MnFe}_{2} \mathrm{O}_{4}$ nanoparticles were dispersed in distilled water under ultrasound irradiation and chitosan in acetic acid solution was slowly 
<smiles>O=c1c(=O)c2ccccc2c1=O</smiles>

1

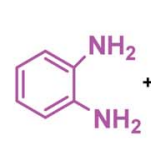

2<smiles>CC1C(=O)c2ccccc2C1=O</smiles>

3

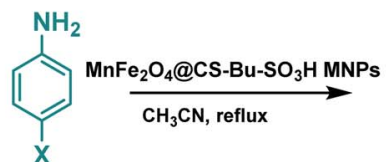

4

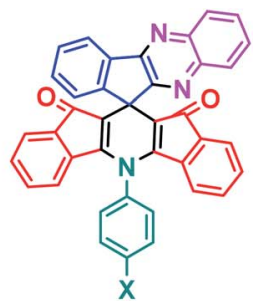

$5 a-m$

Scheme 1 Synthesis of 5-phenyl-spiro[diindenopyridine-indenoquinoxaline]-dione using $\mathrm{MnFe}_{2} \mathrm{O}_{4} @ \mathrm{CSS}-\mathrm{Bu}-\mathrm{SO}_{3} \mathrm{H}$ MNPs.

added under vigorous stirring for $1 \mathrm{~h}$. The magnetically heterogeneous organocatalyst $\mathrm{MnFe}_{2} \mathrm{O}_{4} @ \mathrm{CS}-\mathrm{Bu}_{-} \mathrm{SO}_{3} \mathrm{H}$ MNPs were characterized by X-ray diffraction (XRD), scanning electron

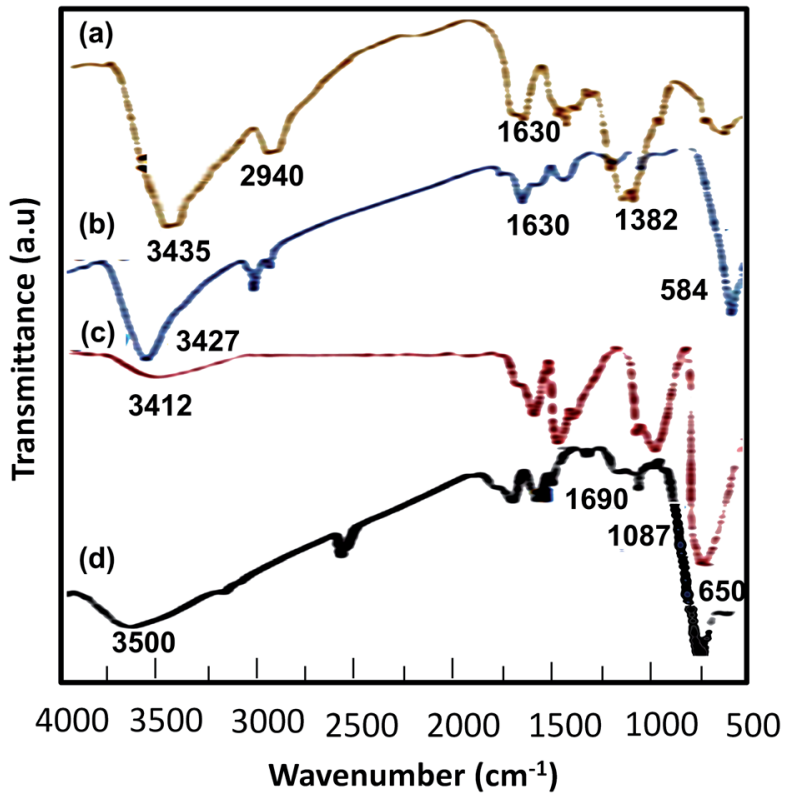

Fig. 1 IR spectra of (a) chitosan (CS), (b) $\mathrm{MnFe}_{2} \mathrm{O}_{4}$, (c) $\mathrm{MnFe}_{2} \mathrm{O}_{4} \mathrm{aCS}$ $\mathrm{NPs}$ and (d) $\mathrm{MnFe}_{2} \mathrm{O}_{4} \mathrm{CCS}-\mathrm{Bu}-\mathrm{SO}_{3} \mathrm{H}$ MNPs.

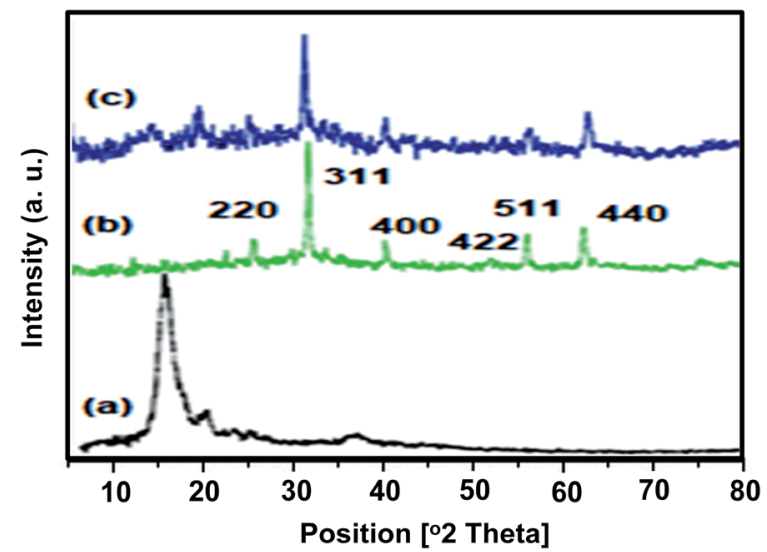

Fig. 2 XRD patterns of (a) chitosan (CS), (b) $\mathrm{MnFe}_{2} \mathrm{O}_{4}$, and (c) $\mathrm{MnFe}_{2} \mathrm{O}_{4} \mathrm{aCS}-\mathrm{Bu}-\mathrm{SO}_{3} \mathrm{H}$ MNPs. microscopy (SEM), energy-dispersive X-ray spectroscopy (EDX), vibrating sample magnetometry (VSM), thermal gravimetric analysis (TGA) and Fourier transform infrared (FT-IR) spectroscopy.

2.1.1 FT-IR analysis. The FT-IR spectra (Fig. 1) of (a) chitosan, (b) $\mathrm{MnFe}_{2} \mathrm{O}_{4}$, (c) $\mathrm{MnFe}_{2} \mathrm{O}_{4} @ \mathrm{CS}$ NPs and (d) $\mathrm{MnFe}_{2} \mathrm{O}_{4}$ @$\mathrm{CS}-\mathrm{Bu}-\mathrm{SO}_{3} \mathrm{H}$ MNPs are instructive. The $\mathrm{O}-\mathrm{H}$ stretching vibration was detected at 3428 and $3433 \mathrm{~cm}^{-1}$ in the peaks of Fig. 1a-d. The FT-IR spectrum of chitosan was characterized by the following absorption bands: the $(\mathrm{NH})$ of the polymer backbone at 3435 and $1630 \mathrm{~cm}^{-1}$, the (C-O) of the primary alcoholic group at $1382 \mathrm{~cm}^{-1}$, and $(\mathrm{C}-\mathrm{H})$ at $2940 \mathrm{~cm}^{-1}$ (Fig. 1a). The FT-IR spectrum of $\mathrm{MnFe}_{2} \mathrm{O}_{4}$ showed characteristic peaks at $3427 \mathrm{~cm}^{-1}$ and $1630 \mathrm{~cm}^{-1}$ which were assigned to the vibration of hydroxyl groups; in addition, an obvious peak at $584 \mathrm{~cm}^{-1}$ was attributed to the $\mathrm{Fe}-\mathrm{O}$ bond vibration (Fig. 1b). Compared with curve $b$, curve $c$ shows the most significant band shift of $\mathrm{Fe}-\mathrm{O}$ stretching (from 584 to $657 \mathrm{~cm}^{-1}$ ), indicating that iron ions bind to the $\mathrm{NH}_{2}$ group of chitosan. Electrostatic interaction between the negatively charged $\mathrm{MnFe}_{2} \mathrm{O}_{4}$ nanoparticle surface and the positively charged protonated chitosan also contributes to the IR change. The peak at $3412 \mathrm{~cm}^{-1}$ was probably the amino group of chitosan, which is overlapped by the $\mathrm{O}-\mathrm{H}$ stretching vibration of $\mathrm{MnFe}_{2} \mathrm{O}_{4}$ nanoparticles (Fig. 1c). The FTIR spectrum of $\mathrm{MnFe}_{2} \mathrm{O}_{4}$ @CS-Bu-SO $\mathrm{S}_{3} \mathrm{H}$ MNPs shows the stretching and out-of-plane bending of acidic $\mathrm{O}-\mathrm{H}$ groups as two broad bands at $2800-3500 \mathrm{~cm}^{-1}$. Also, the $\mathrm{S}=\mathrm{O}$ stretching bands of the $-\mathrm{SO}_{3} \mathrm{H}$ group appeared at $1000-1200 \mathrm{~cm}^{-1}$ (Fig. 1d).

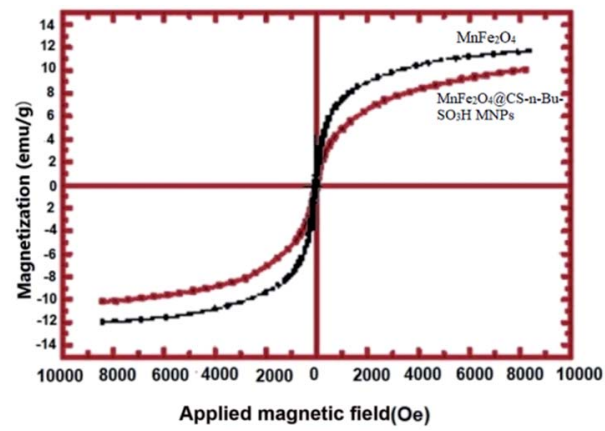

Fig. 3 Magnetization versus applied field for $\mathrm{MnFe}_{2} \mathrm{O}_{4}$ and $\mathrm{MnFe}_{2}{ }^{-}$ $\mathrm{O}_{4}$ (aCS-Bu-SO $\mathrm{H}_{3} \mathrm{MNPs}$ 


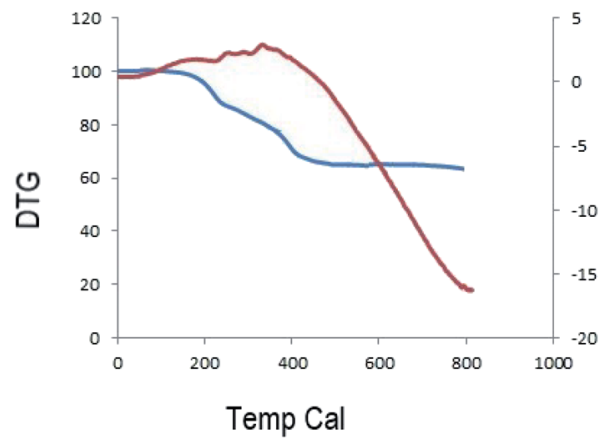

Fig. 4 The thermal gravimetric analysis (TGA) of $\mathrm{MnFe}_{2} \mathrm{O}_{4}$ (aCS-Bu$\mathrm{SO}_{3} \mathrm{H}$ NPs.

2.1.2 X-ray diffraction (XRD) analysis. The crystal structures of chitosan and $\mathrm{MnFe}_{2} \mathrm{O}_{4} @ \mathrm{CS}-n$-Bu-SO $\mathrm{S}_{3} \mathrm{H}$ MNPs are shown in Fig. 2. The sharp peaks in the XRD patterns confirm the good crystallinity of the prepared samples. There are six diffraction peaks at $2 \theta$ values of about $29.94^{\circ}, 35.24^{\circ}, 42.75^{\circ}, 52.94^{\circ}, 56.42^{\circ}$ and $61.86^{\circ}$, corresponding to the (220), (311), (400), (422), (511), and (440) planes in the $\mathrm{MnFe}_{2} \mathrm{O}_{4} @ \mathrm{CS}-n$ - $\mathrm{Bu}-\mathrm{SO}_{3} \mathrm{H}$ MNPs, which is the standard pattern for crystalline magnetite with cubic structure (JCPDS card no. 01-1111). The small and weak broad bands in the range of $12-20^{\circ}$ show the existence of amorphous chitosan. The average crystal sizes of pure $\mathrm{MnFe}_{2} \mathrm{O}_{4}$ and chitosan-coated $\mathrm{MnFe}_{2} \mathrm{O}_{4}$ nanoparticles are 19 and 25, respectively.

2.1.3 Magnetic properties. The magnetization curves for $\mathrm{MnFe}_{2} \mathrm{O}_{4}$ nanoparticles and $\mathrm{MnFe}_{2} \mathrm{O}_{4} @ \mathrm{CS}-\mathrm{Bu}_{-} \mathrm{SO}_{3} \mathrm{H}$ MNPs nanoparticles are shown in Fig. 3. Room temperature specific magnetization versus applied magnetic field curve measurements of the $\mathrm{MnFe}_{2} \mathrm{O}_{4} @ \mathrm{CS}-\mathrm{Bu}-\mathrm{SO}_{3} \mathrm{H}$ MNPs indicate a saturation magnetization value of $10.27 \mathrm{emu} \mathrm{g}^{-1}$, lower than that of the pristine $\mathrm{MnFe}_{2} \mathrm{O}_{4}$ nanoparticles (12.69 $\mathrm{emu} \mathrm{g}^{-1}$ ) due to the coated shell.

2.1.4 Thermal gravimetric analysis (TGA). In order to obtain information on the thermal stability, TGA experiments were carried out by heating $\mathrm{MnFe}_{2} \mathrm{O}_{4} @ \mathrm{CS}-\mathrm{Bu}-\mathrm{SO}_{3} \mathrm{H}$ MNPs up to $800{ }^{\circ} \mathrm{C}$ (Fig. 4). The weight loss of $\mathrm{MnFe}_{2} \mathrm{O}_{4} @ \mathrm{CS}-\mathrm{Bu}_{-} \mathrm{SO}_{3} \mathrm{H}$ MNPs nanoparticles is about $40 \%$ in the range $250-420{ }^{\circ} \mathrm{C}$, corresponding to the thermal decomposition of the chitosan chains over $\mathrm{MnFe}_{2} \mathrm{O}_{4}$ nanoparticles.

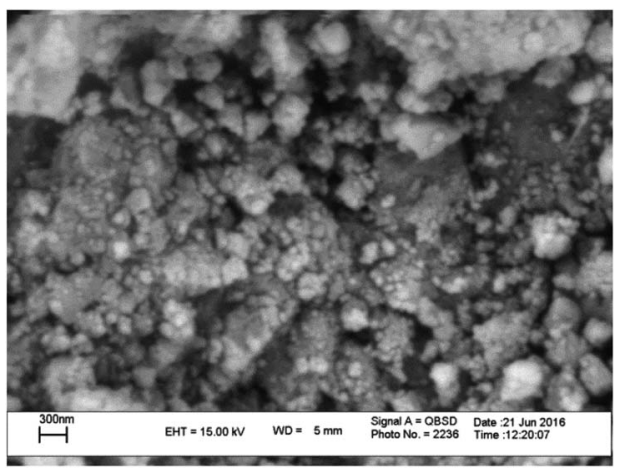

Fig. 5 SEM image of $\mathrm{MnFe}_{2} \mathrm{O}_{4} \mathrm{aCS}-\mathrm{Bu}-\mathrm{SO}_{3} \mathrm{H}$ MNPs.

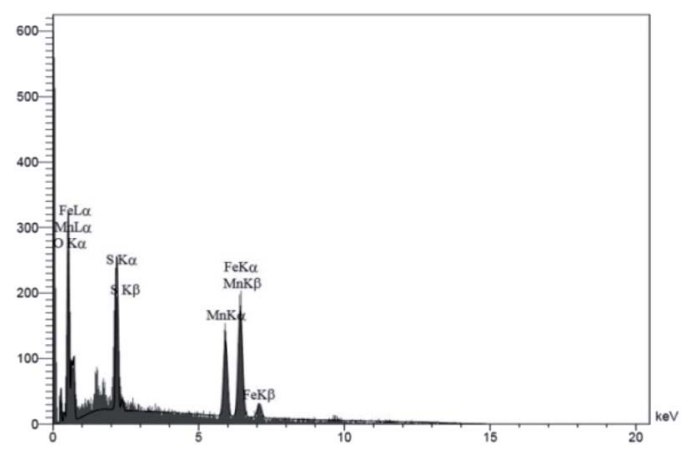

Fig. 6 The energy dispersive $\mathrm{X}$-ray (EDX) spectrum of $\mathrm{MnFe}_{2} \mathrm{O}_{4} \mathrm{QCS}-$ $\mathrm{Bu}-\mathrm{SO}_{3} \mathrm{H}$ MNPs.

2.1.5 Scanning electron microscopy (SEM). Fig. 5 exhibits the morphology and particle size of $\mathrm{MnFe}_{2} \mathrm{O}_{4}$ @CS-Bu- $\mathrm{SO}_{3} \mathrm{H}$ MNPs. It indicates that the chitosan polymeric matrix uniformly covers the surface of $\mathrm{MnFe}_{2} \mathrm{O}_{4}$ (Fig. 5). The SEM image shows that the structural size of $\mathrm{MnFe}_{2} \mathrm{O}_{4} @ \mathrm{CS}-\mathrm{Bu}_{-} \mathrm{SO}_{3} \mathrm{H}$ MNPs is bigger. The SEM of $\mathrm{MnFe}_{2} \mathrm{O}_{4} @ \mathrm{CS}-\mathrm{Bu}-\mathrm{SO}_{3} \mathrm{H}$ MNPs clearly reveals the structure of the CS-coated magnetite nanoparticles.

2.1.6 Energy dispersive X-ray (EDX) spectroscopy. The elemental compositions are calculated from the energy dispersive X-ray (EDX) spectrum. The elemental composition of $\mathrm{MnFe}_{2} \mathrm{O}_{4} @ \mathrm{CS}-\mathrm{Bu}_{-} \mathrm{SO}_{3} \mathrm{H}$ MNPs is $3.01 \%, \quad 11.56 \%, 6.83 \%$, $29.73 \%, 30.74 \%$ and $18.12 \%$ for $\mathrm{N}, \mathrm{C}, \mathrm{S}, \mathrm{O}, \mathrm{Fe}$ and $\mathrm{Mn}$, respectively. This implies that the chitosan polymer was coated on the surface of the $\mathrm{MnFe}_{2} \mathrm{O}_{4}$ NPs (Fig. 6).

Moreover, in accordance with the SEM image of the $\mathrm{MnFe}_{2} \mathrm{O}_{4} @ \mathrm{CS}-\mathrm{Bu}-\mathrm{SO}_{3} \mathrm{H}$ nanoparticles, the particle size distribution histogram is shown in Fig. 7. As can be observed, the dispersed nanoparticles formed with a uniform size and the mean value and standard deviation could be estimated as $27 \pm$ $3 \mathrm{~nm}$ from this size distribution histogram.

\subsection{Investigation of catalyst activity in organic reactions}

In the present work, we investigated the model reaction of ninhydrin, 1,2-diamino benzene, 1,3-indandione and anilines

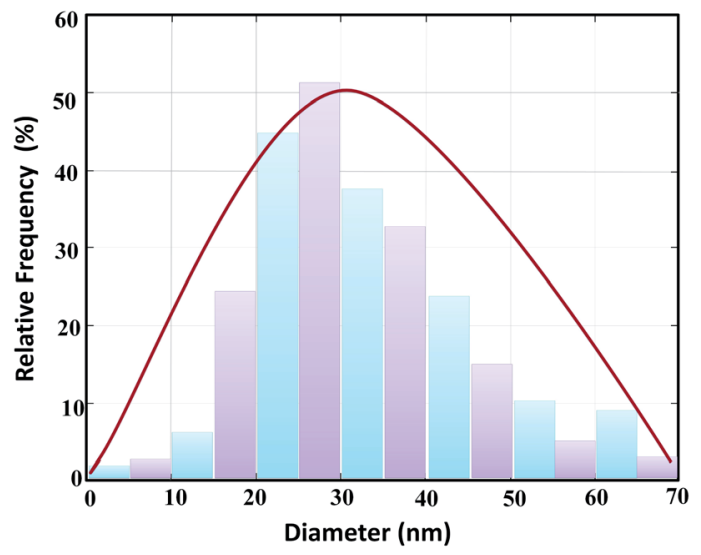

Fig. 7 Particle size distribution histogram of the catalyst. 
Table 1 The reaction in the presence of different solvents and $\mathrm{MnFe}_{2} \mathrm{O}_{4} \mathrm{OCS}-\mathrm{Bu}-\mathrm{SO}_{3} \mathrm{H} \mathrm{MNPs}^{a}$

\begin{tabular}{llcl}
\hline Entry & Solvent & Time (h) & Yield $^{b}(\%)$ \\
\hline 1 & $\mathrm{H}_{2} \mathrm{O}$ & 18 & 38 \\
2 & $\mathrm{EtOH}$ & 15 & 43 \\
3 & $\mathrm{CH}_{3} \mathrm{CN}$ & 3 & 97 \\
4 & $\mathrm{CHCl}_{3}$ & 24 & 31
\end{tabular}

${ }^{a}$ Reaction conditions: ninhydrin $1.0 \mathrm{mmol}, 1,2$-diamino benzene $1.0 \mathrm{mmol}, 1,3$-indandione $2.0 \mathrm{mmol}$ and anilines $1.0 \mathrm{mmol}$ under heat. ${ }^{b}$ Isolated yields.

in the presence of $\mathrm{MnFe}_{2} \mathrm{O}_{4}$ @CS-Bu-SO $\mathrm{S}_{3} \mathrm{H}$ MNPs under heat condition. In this research, the effects of different solvents and various amounts of catalyst on the model reaction were examined. First, several organic solvents, such as $\mathrm{H}_{2} \mathrm{O}, \mathrm{CH}_{3} \mathrm{CN}$, EtOH and $\mathrm{CHCl}_{3}$, were examined (Table 1 ). According to the data given in Table 1 , entry $3, \mathrm{CH}_{3} \mathrm{CN}$ was the most efficient solvent for this reaction.

Furthermore, various catalysts and different amounts of catalyst were used in the sample reaction (Table 2). No reaction was observed in the absence of catalyst without heat (Table 2, entry 1). When the reaction was performed at room temperature in the presence of $\mathrm{MnFe}_{2} \mathrm{O}_{4}$ @CS-Bu-SO $\mathrm{S}_{3} \mathrm{H}$ MNPs, the product was obtained in lower yield and with longer reaction time (Table 2, entry 6), while heat and $\mathrm{MnFe}_{2} \mathrm{O}_{4}$ @CS- $n$-butyl $\mathrm{SO}_{3} \mathrm{H}$ NPs gave the best yield in the shortest time. An excellent yield of $97 \%$ was obtained with $20 \mathrm{~mol} \%$ catalyst (Table 2, entry 8) and was not improved by increasing to $30 \mathrm{~mol} \%$ (Table 2, entry 9).

We also applied $\mathrm{MnFe}_{2} \mathrm{O}_{4} @ \mathrm{CS}-\mathrm{Bu}-\mathrm{SO}_{3} \mathrm{H}$ MNPs catalyst for the synthesis of 5-phenyl-spiro[diindenopyridineindenoquinoxaline]-dione derivatives from various aromatic amines under similar conditions, as seen in Table 3 . The results indicate that excellent yields were achieved in the reaction in the presence of $\mathrm{MnFe}_{2} \mathrm{O}_{4} @ \mathrm{CS}-\mathrm{Bu}-\mathrm{SO}_{3} \mathrm{H}$ MNPs (20 mol\%) under reflux conditions. The influence of electron-withdrawing and electron-donating substituents on the aromatic ring of amines upon the reaction yields was investigated. Electron-releasing substituents on aromatic amines gave good to excellent yields of 5-phenyl-spiro[diindenopyridine-indenoquinoxaline]-dione derivatives under the above-mentioned conditions. The highest yields of 5-phenyl-spiro[diindenopyridineindenoquinoxaline]-dione derivatives were obtained using the electron-releasing para-methyl group as a substituent for aromatic amines.

Furthermore, comparison of the reactions in the presence of p-TSA catalyst, as previously reported, ${ }^{6}$ with the present work was carried out on production of $\mathbf{5 a}, \mathbf{5 j}$ and $\mathbf{5 k}$. The results are listed in Table 4. As shown, the product yields using the present method were higher than those from the previously reported method and the reaction times were shorter than those obtained in the reported work (Table 4, entries 2, 4, 6 vs. 1, 3, 5).

The proposed reaction mechanism for the synthesis of spiro indenoquinoxalines catalyzed by $\mathrm{MnFe}_{2} \mathrm{O}_{4} @ \mathrm{CS}-n-\mathrm{Bu}_{-} \mathrm{SO}_{3} \mathrm{H}$ MNPs is depicted in Scheme 2. As shown in Scheme 2, compound 5 could be synthesized via sequential iminizationaromatization, condensation, addition, enamination and cyclization. Initially, the $\mathrm{MnFe}_{2} \mathrm{O}_{4} @ \mathrm{CS}-n-\mathrm{Bu}_{-} \mathrm{SO}_{3} \mathrm{H}$ MNPs catalyst protonates the carbonyl group of ninhydrin (1); this step is regarded as a fast iminization-aromatization reaction in which the ninhydrin (1) first reacts with 1,2-diamino benzene (2) to afford $11 \mathrm{H}$ indeno[2,1- $b]$ quinoxalin-11-one (A) in the presence of $\mathrm{MnFe}_{2} \mathrm{O}_{4} @ \mathrm{CS}-\mathrm{Bu}-\mathrm{SO}_{3} \mathrm{H}$ MNPs in acetonitrile. Then, the catalyst protonates the carbonyl group of compound $\mathbf{A}$ and compound $\mathbf{A}$ is condensed with 1,3-indenedione (3) to afford compound B. This step is regarded as a fast Knoevenagel condensation reaction. Then, compound $\mathbf{B}$ is attacked by another 1,3-indene dione (3) in a Michael-type addition to produce intermediate C. Finally, compound $\mathbf{C}$ reacted with aniline (4) to produce compound $\mathbf{D}$, followed by intramolecular cyclization and tautomerization to afford the product (5).

Reusability is one of the significant properties of this catalyst. The reusability of $\mathrm{MnFe}_{2} \mathrm{O}_{4}$ @CS-Bu-SO $\mathrm{SO}_{3} \mathrm{H}$ MNPs was studied for the reaction of ninhydrin, 1,2-diamino benzene, 1,3indandione and anilines. After completion of the reaction, the nanocatalyst was easily separated using an external magnet. The recovered magnetite nanoparticles were washed several times with acetone and then dried at room temperature (Fig. 8). The results of five consecutive runs $(98 \%, 98 \%, 97 \%, 96 \%$ and $96 \%$ ) indicated that the yields remained similar with no detectable loss of yield or catalytic activity.

Table 2 Optimization of the various amounts and types of catalysts ${ }^{a}$

\begin{tabular}{|c|c|c|c|c|}
\hline Entry & Condition & Catalyst (mol\%) & Time (h) & Yield $^{b}(\%)$ \\
\hline 1 & R.T. & - & 48 & - \\
\hline 2 & Heat & $\mathrm{Et}_{3} \mathrm{~N}$ & 24 & 10 \\
\hline 4 & Heat & Nano $\mathrm{Fe}_{3} \mathrm{O}_{4}$ & 20 & 43 \\
\hline 5 & Heat & Nano $\mathrm{MnFe}_{2} \mathrm{O}_{4}$ & 18 & 48 \\
\hline 6 & R.T. & $\mathrm{MnFe}_{2} \mathrm{O}_{4} @ \mathrm{CS}-\mathrm{Bu}-\mathrm{SO}_{3} \mathrm{H}$ NPs (10) & 48 & 10 \\
\hline 9 & Heat & $\mathrm{MnFe}_{2} \mathrm{O}_{4} @ \mathrm{CS}-\mathrm{Bu}-\mathrm{SO}_{3} \mathrm{H}$ NPs (30) & 3 & 97 \\
\hline
\end{tabular}

${ }^{a}$ Reaction conditions: ninhydrin $1.0 \mathrm{mmol}, 1$,2-diamino benzene $1.0 \mathrm{mmol}, 1,3$-indandione $2.0 \mathrm{mmol}$ and anilines $1.0 \mathrm{mmol} .{ }^{b}$ Isolated yields. 
Table 3 Synthesis of various 5-phenyl-spiro[diindenopyridine-indenoquinoxaline]-dione derivatives using $\mathrm{MnFe}_{2} \mathrm{O}_{4} \mathrm{OCS}^{-\mathrm{Bu}-\mathrm{SO}_{3} \mathrm{H}} \mathrm{MNPs}^{a}$

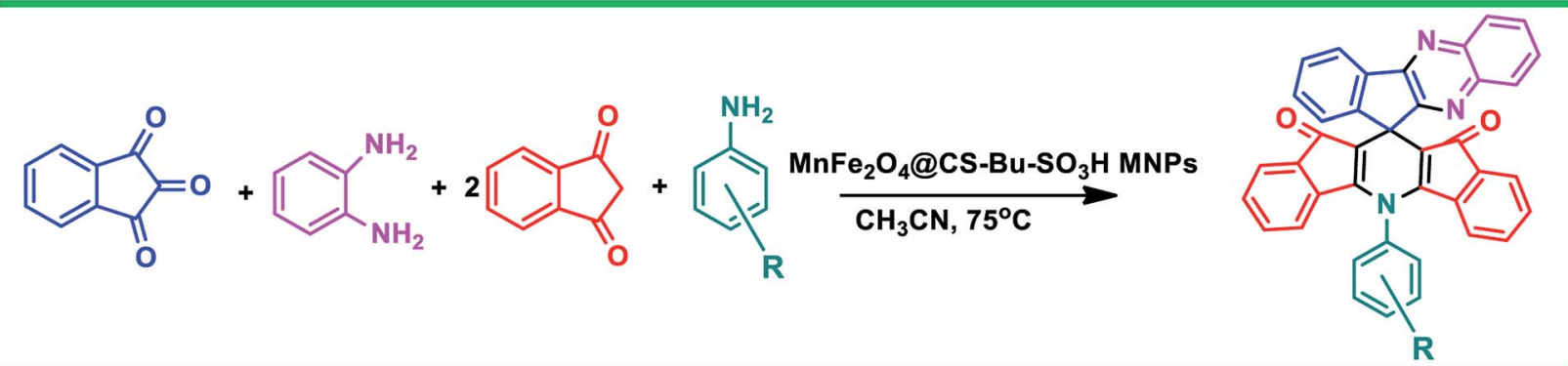

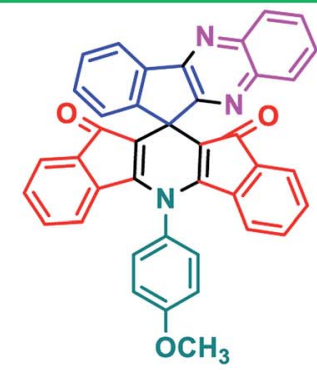

5a: $95 \%, 3 h$<smiles>O=C1C2=C(c3ccccc31)N(c1cccc([N+](=O)[O-])c1)C1=C(C(=O)c3ccccc31)C21C(=O)c2ccccc2-c2nc3ccccc3nc21</smiles>

5e: $80 \%, 3.5 h$<smiles>Cc1ccc(N2C3=C(C(=O)c4ccccc43)C3(C4=C(C(=O)c5ccccc54)c4ccccc43)c3nc4ccccc4nc32)c(C)c1</smiles>

5i: $95 \%, 3 h$

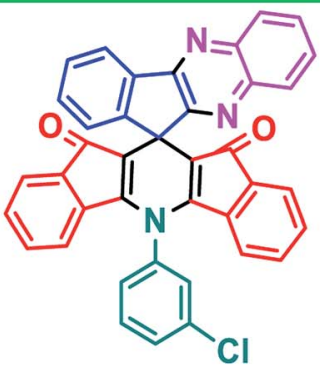

$5 b: 82 \%, 3.5 h$

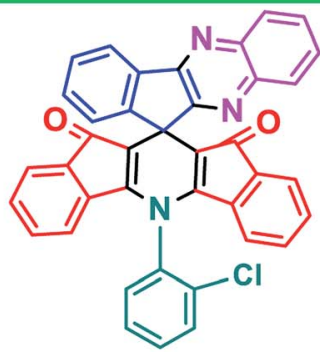

5f: $82 \%, 3.5 h$

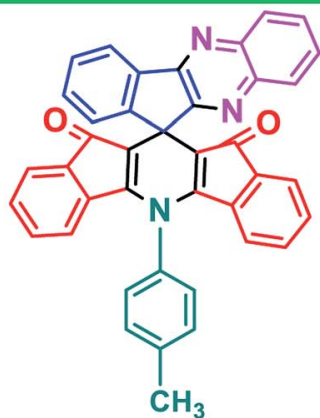

$5 \mathrm{j}: \mathbf{9 7 \%}, \mathbf{3 h}$<smiles>O=C1C2=C(c3ccccc31)N(c1ccc(O)cc1)C1=C(C(=O)c3ccccc31)C21c2ccccc2-c2nc3ccccc3nc21</smiles>

5c: $91 \%, 3 \mathrm{~h}$

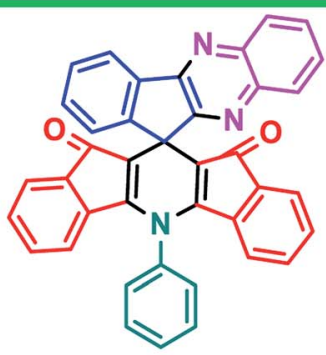

5g: $93 \%, 3 h$

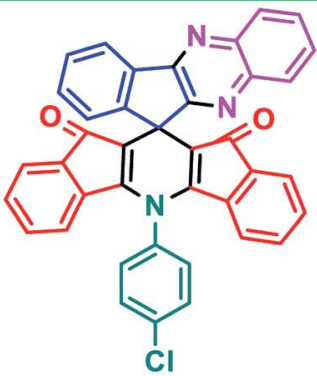

5d: $84 \%, 3 h$

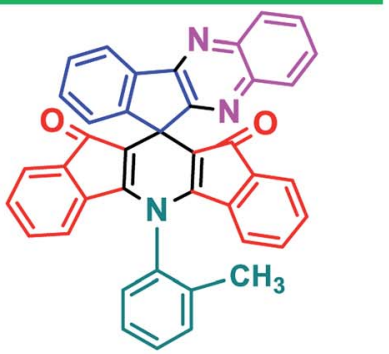

5h: $93 \%, 3 h$

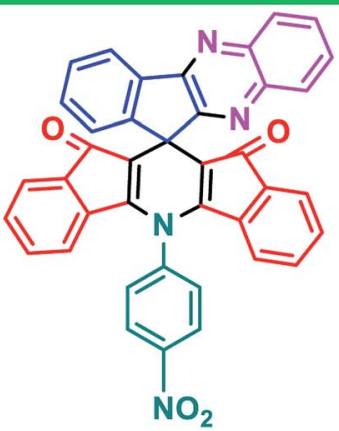

5k: $83 \%, 3.5 \mathrm{~h}$

${ }^{a}$ Isolated yield.

Table 4 Comparison between previously reported work and the present work

\begin{tabular}{|c|c|c|c|c|c|c|}
\hline En. & Catalyst & Cond. & Prod. & Time (h) & Yield (\%) & Ref. \\
\hline 1 & $p$-TSA (30 mol\%) & $\mathrm{H}_{3} \mathrm{CCN}, 82{ }^{\circ} \mathrm{C}$ & $5 a$ & 16 & 71 & 6 \\
\hline 2 & $\mathrm{MnFe}_{2} \mathrm{O}_{4} @ \mathrm{CS}-\mathrm{Bu}-\mathrm{SO}_{3} \mathrm{H}$ & $\mathrm{H}_{3} \mathrm{CCN}, 75^{\circ} \mathrm{C}$ & $5 a$ & 3 & 95 & This work \\
\hline 4 & $\mathrm{MnFe}_{2} \mathrm{O}_{4} @ \mathrm{CS}-\mathrm{Bu}-\mathrm{SO}_{3} \mathrm{H}$ & $\mathrm{H}_{3} \mathrm{CCN}, 75^{\circ} \mathrm{C}$ & $5 \mathbf{j}$ & 3 & 97 & This work \\
\hline 5 & $p$-TSA $(30 \mathrm{~mol} \%)$ & $\mathrm{H}_{3} \mathrm{CCN}, 82^{\circ} \mathrm{C}$ & $5 \mathbf{k}$ & 16 & 62 & 6 \\
\hline 6 & $\mathrm{MnFe}_{2} \mathrm{O}_{4} @ \mathrm{CS}-\mathrm{Bu}-\mathrm{SO}_{3} \mathrm{H}$ & $\mathrm{H}_{3} \mathrm{CCN}, 75^{\circ} \mathrm{C}$ & $5 \mathbf{k}$ & 3.5 & 83 & This work \\
\hline
\end{tabular}




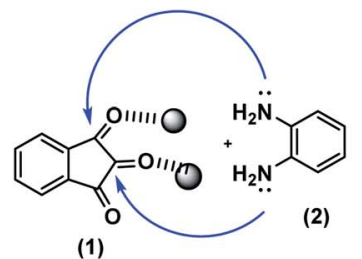

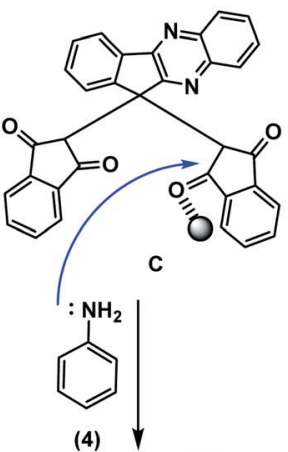

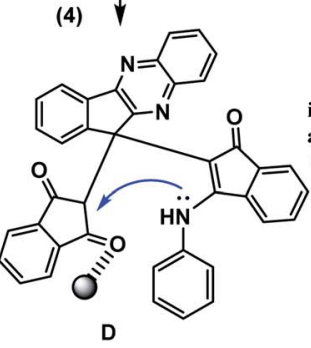

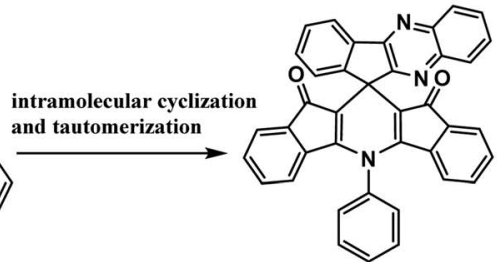

(5)

\section{$: \mathrm{MnFe}_{2} \mathrm{O}_{4} @ \mathrm{CS}-\mathrm{n}-\mathrm{Bu}-\mathrm{SO}_{3} \mathrm{H}$ MNPs}

Scheme 2 Plausible mechanism for the synthesis of spiro indenoquinoxalines.

In order to investigate any structural change of the catalyst, the XRD pattern (Fig. 9) and FT-IR spectrum (Fig. 10) of the recovered catalyst were obtained. The results show well-defined peaks at the $2 \theta$ values of the XRD pattern related to the unused catalyst and conformity of the FT-IR spectrum to that of the unused catalyst; thus, there is no structural change in the catalyst after the reaction.

\section{Conclusions}

In this research, we have developed an effective procedure for the synthesis of 5-phenyl-spiro[diindenopyridineindenoquinoxaline]-dione derivatives by a one-pot fourcomponent reaction of ninhydrin, 1,2-diamino benzene, 1,3indandione and anilines using $\mathrm{MnFe}_{2} \mathrm{O}_{4} @ \mathrm{CS}-\mathrm{Bu}_{-} \mathrm{SO}_{3} \mathrm{H}$ MNPs as

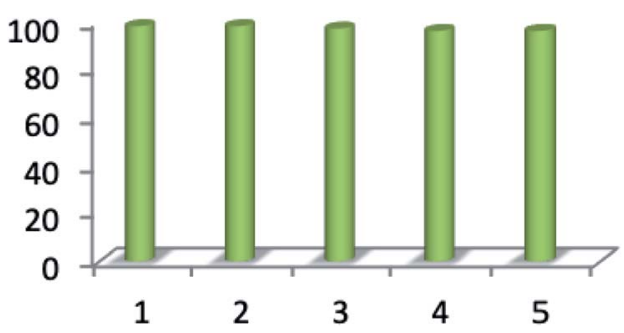

Fig. 8 Reusability of catalyst for synthesis of spiro indenoquinoxaline. a nano magnetic catalyst. High yields, a simple reaction process, easy work-up, shorter reaction times, reusability of the catalyst and low catalyst loading are some of the considerable advantages of the current protocol.

\section{Experimental method}

\subsection{Materials}

The chemicals used in this work were obtained from Fluka and Merck Chemical Companies and were used without purification.

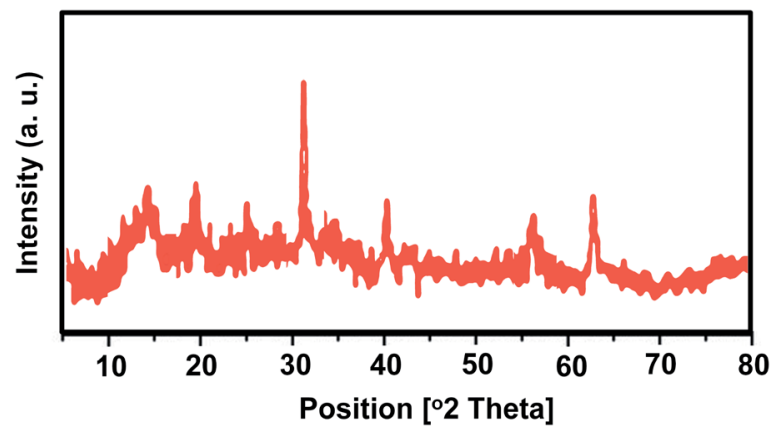

Fig. 9 XRD pattern of recovered catalyst. 


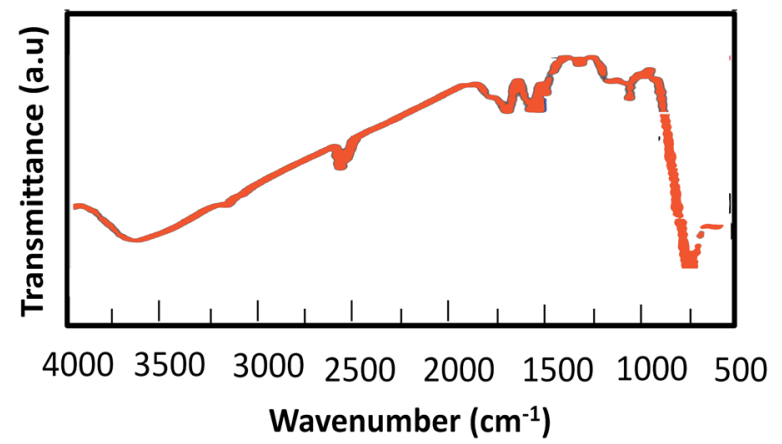

Fig. 10 FT-IR spectrum of recovered catalyst.

\subsection{Apparatus}

FT-IR spectra were obtained with potassium bromide pellets in the range $400-4000 \mathrm{~cm}^{-1}$ with a PerkinElmer 550 spectrometer. ${ }^{1} \mathrm{H}$ NMR and ${ }^{13} \mathrm{C}$ NMR spectra were recorded with a Bruker DRX-400 spectrometer at 400 and $100 \mathrm{MHz}$, respectively. NMR spectra were reported as parts per million (ppm) downfield from tetramethylsilane as the internal standard. The abbreviations used are singlet (s), doublet (d), triplet $(\mathrm{t})$ and multiplet $(\mathrm{m})$. Nanostructures were characterized using a Holland Philips Xpert X-ray powder diffraction (XRD) diffractometer (CuK $\alpha$, radiation, $k=0.154056 \mathrm{~nm}$ ) at a scanning speed of $2^{\circ} \mathrm{min}^{-1}$ from $10^{\circ}$ to $100^{\circ}(2 \theta)$. A BANDELIN ultrasonic HD 3200 with probe model KE 76 with a diameter of $6 \mathrm{~mm}$ was used to produce ultrasonic irradiation and homogenize the reaction mixture. The piezoelectric crystal of this kind of probe normally works in the range of $700 \mathrm{kHz}$, but by using the proper clamps, the output frequency of the piezoelectric crystal was controlled and reduced to $20 \mathrm{kHz}$. Therefore, the induced frequency of the probe for the reaction mixture is equal to $20 \mathrm{kHz}$. A thermal method was used for the calibration of ultrasonic power. Melting points were determined in open capillaries using an Electrothermal Mk3 apparatus and are uncorrected. The purity determination of the substrates and reaction monitoring were accomplished by TLC on silica-gel polygram SILG/UV 254 plates (Merck). FE-SEM images of the products were visualized by an Oxford Instruments Sigma ZEISS field emission scanning electron microscope. The magnetic properties of the nanoparticles were measured with a vibrating sample magnetometer (VSM, PPMS-9T) at $300 \mathrm{~K}$ in Iran (University of Kashan).

\subsection{Typical experimental procedure for the preparation of chitosan-coated magnetic nanoparticles $\mathrm{MnFe}_{2} \mathrm{O}_{4} @ C S$ NPs}

In this research, the $\mathrm{MnFe}_{2} \mathrm{O}_{4}$ nanoparticles were prepared by following the reported standard protocol: co-precipitation of
$\mathrm{MnCl}_{2}$ and $\mathrm{FeCl}_{3}$ in water in the presence of sodium hydroxide. Briefly, $\mathrm{MnCl}_{2} \cdot 4 \mathrm{H}_{2} \mathrm{O}$ and $\mathrm{FeCl}_{3} \cdot 6 \mathrm{H}_{2} \mathrm{O}$ were used in the molar ratio of $\mathrm{Mn}^{2+}: \mathrm{Fe}^{3+}=1: 2$ to prepare a $0.4 \mathrm{~mol} \mathrm{~L}^{-1}$ metal ion solution of $100 \mathrm{ml}$ containing $0.2 \mathrm{~mol} \mathrm{~L}{ }^{-1} \mathrm{Mn}^{2+}$ and $0.4 \mathrm{~mol} \mathrm{~L}^{-1} \mathrm{Fe}^{3+}$ which was then dropped slowly into $100 \mathrm{ml} \mathrm{NaOH}$ solution of $5 \mathrm{~mol} \mathrm{~L}^{-1}$ at the temperature of $97{ }^{\circ} \mathrm{C}$. After aging for $2 \mathrm{~h}$ with continuous stirring, the mixture was filtered, washed and dried at $60{ }^{\circ} \mathrm{C}$ for $24 \mathrm{~h}$. Next, the reaction mixture was cooled and the catalyst was isolated in a magnetic field and washed three times with distilled water. Subsequently, in order to prepare $\mathrm{MnFe}_{2} \mathrm{O}_{4}$-chitosan nanoparticles, $1 \mathrm{~g}$ of the $\mathrm{MnFe}_{2} \mathrm{O}_{4}$ nanoparticles was dispersed in $120 \mathrm{ml}$ distilled water under ultrasound irradiation and $0.5 \mathrm{~g}$ of chitosan in $120 \mathrm{ml}$ of $2.0 \mathrm{wt} \%$ acetic acid solution was slowly added under vigorous stirring at $50{ }^{\circ} \mathrm{C}$ for $1 \mathrm{~h}$. The modified $\mathrm{MnFe}_{2} \mathrm{O}_{4}$-chitosan nanoparticles were recovered by magnetic decantation and washed with $\mathrm{CH}_{2} \mathrm{Cl}_{2}$. Finally, $\mathrm{MnFe}_{2} \mathrm{O}_{4}$-chitosan nanoparticles were dried at $60{ }^{\circ} \mathrm{C}$.

\subsection{Preparation of 1,4 -butane sultone chitosan- encapsulated manganese ferrite nanoparticles $\left(\mathrm{MnFe}_{2} \mathrm{O}_{4} @ \mathrm{CS}\right.$ - n-Bu-SO $\mathrm{SO}_{3} \mathrm{HNPs}$ )}

$\mathrm{MnFe}_{2} \mathrm{O}_{4}$-chitosan nanoparticles and 1,4-butane sultone $(0.36 \mathrm{ml}, 3 \mathrm{mmol})$ were mixed together without solvent and stirred for $3 \mathrm{~h}$ at room temperature $\left(25^{\circ} \mathrm{C}\right)$. Concentrated $\mathrm{H}_{2} \mathrm{SO}_{4}$ $(0.154 \mathrm{ml}, 3 \mathrm{mmol})$ was added to the above catalyst mixture and refluxed for $2 \mathrm{~h}$. The final catalyst was washed repeatedly with ethanol and then dried (Scheme 3).

\subsection{General procedure for the synthesis of spiro indenoquinoxalines catalyzed by $\mathrm{MnFe}_{2} \mathrm{O}_{4} @ \mathrm{CS}-\mathrm{Bu}_{-} \mathrm{SO}_{3} \mathrm{H}$ MNPs}

A mixture of ninhydrin ( $1 \mathrm{mmol}), 1$,2-diamino benzene (1 mmol), and $\mathrm{MnFe}_{2} \mathrm{O}_{4} @ \mathrm{CS}-\mathrm{Bu}-\mathrm{SO}_{3} \mathrm{H}$ MNPs $(20 \mathrm{mg}$ ) in $5 \mathrm{ml}$ acetonitrile was heated at $75{ }^{\circ} \mathrm{C}$ for $5 \mathrm{~min}$, then 1,3-indandione $(2 \mathrm{mmol})$ and aniline $(1 \mathrm{mmol})$ were added to the mixture and stirred for $3 \mathrm{~h}$. Progress of the reaction was continuously monitored by TLC. On completion of the reaction, the reaction mixture was cooled to room temperature and the catalyst was separated by an external magnet. Then, the precipitated product was filtered and washed in $3 \mathrm{ml}$ ethanol to afford the pure product.

\subsection{Representative spectral data}

4.6.1 5-(4-Methoxyphenyl)-10H-spiro[diindeno[1,2-b:2 $2^{\prime}, 1^{\prime}-$ $e]$ pyridine-11,11'-indeno[1,2- $b]$ quinoxaline $]-10,12(5 H)$-dione (5a). Dark red solid, Rf ( $n$-hexane : ethylacetate): $7: 3(\mathrm{v} / \mathrm{v})=$

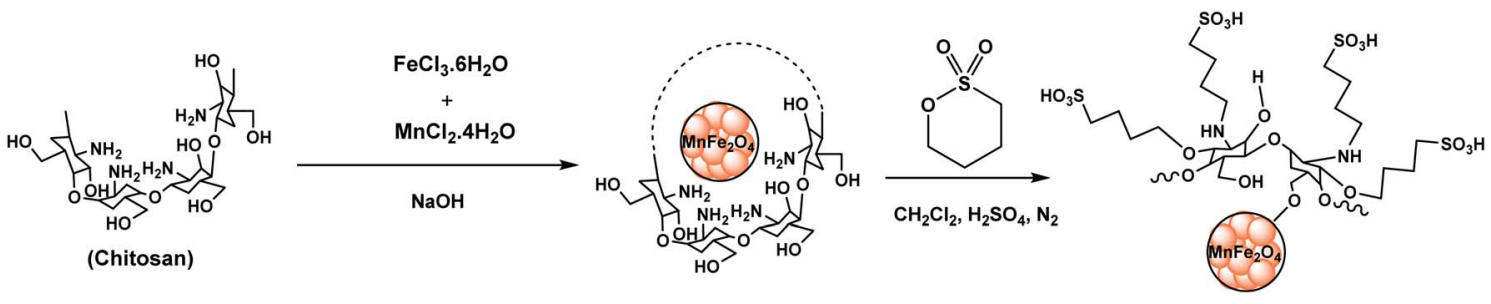

Scheme 3 Preparation steps of $\mathrm{MnFe}_{2} \mathrm{O}_{4} \mathrm{OCS}-\mathrm{Bu}-\mathrm{SO}_{3} \mathrm{H}$ MNPs. 
0.60; (mprep. 233)/(mplit $\left.233-240{ }^{\circ} \mathrm{C}\right) .{ }^{6} \mathrm{IR}(\mathrm{KBr}) \nu: 3436,3060$, 2924, 1699, 1511, 1383, 1252, $1000 \mathrm{~cm}^{-1} ;{ }^{1} \mathrm{H}$ NMR $(400 \mathrm{MHz}$, DMSO-d $\left._{6}\right) \delta: 8.23$ (d, $\left.J=8.0 \mathrm{~Hz}, 1 \mathrm{H}, \operatorname{ArH}\right), 8.18(\mathrm{~m}, 2 \mathrm{H}, \operatorname{ArH})$, $7.99(\mathrm{t}, J=8.0 \mathrm{~Hz}, 2 \mathrm{H}, \mathrm{ArH}), 7.87(\mathrm{~d}, J=8.0 \mathrm{~Hz}, 1 \mathrm{H}, \mathrm{ArH}), 7.78(\mathrm{~d}$, $J=8.0 \mathrm{~Hz}, 2 \mathrm{H}, \operatorname{ArH}), 7.60(\mathrm{t}, J=4.0 \mathrm{~Hz}, 2 \mathrm{H}, \mathrm{ArH}), 7.33(\mathrm{~m}, 2 \mathrm{H}$, ArH), 7.22 (m, 4H, ArH), 7.09 (d, $J=8.0 \mathrm{~Hz}, 2 \mathrm{H}, \mathrm{ArH}), 5.97$ (d, $J=$ $4.0 \mathrm{~Hz}, 2 \mathrm{H}, \mathrm{ArH}), 3.98\left(\mathrm{~s}, 3 \mathrm{H}, \mathrm{OCH}_{3}\right) \mathrm{ppm}$. Anal. calcd for $\mathrm{C}_{40} \mathrm{H}_{23} \mathrm{~N}_{3} \mathrm{O}_{3}$ : C, 80.93; H, 3.91; N, 7.08. Found: C, 80.88; H, $3.86 ; \mathrm{N}, 7.04$.

4.6.2 5-(3-Chlorophenyl)-10H-spiro[diindeno[1,2-b:2' $\left.\mathbf{1}^{\prime}-e\right]$ pyridine-11,11' -indeno[1,2- $b]$ quinoxaline $]-10,12(5 H)$-dione $(5 b)$. Dark red solid, $\operatorname{Rf}(n$-hexane : ethylacetate): $7: 3(\mathrm{v} / \mathrm{v})=0.55 ; \mathrm{mp}$ $284{ }^{\circ} \mathrm{C}$. IR (KBr) $\nu$ : 3432, 3063, 2922, 1700, 1578, 1384, 1301, $999 \mathrm{~cm}^{-1} ;{ }^{1} \mathrm{H}$ NMR (400 MHz, DMSO-d $\left.{ }_{6}\right) \delta: 8.22(\mathrm{~d}, J=8.0 \mathrm{~Hz}$, $1 \mathrm{H}, \operatorname{ArH}), 8.17$ (d, $J=4.0 \mathrm{~Hz}, 2 \mathrm{H}, \operatorname{ArH}), 8.13(\mathrm{t}, J=8.0 \mathrm{~Hz}, 1 \mathrm{H}$, $\operatorname{ArH}), 8.02(\mathrm{~d}, J=8.0 \mathrm{~Hz}, 2 \mathrm{H}, \operatorname{ArH}), 7.86(\mathrm{~m}, 3 \mathrm{H}, \operatorname{ArH}), 7.77(\mathrm{~s}, 1 \mathrm{H}$, ArH), 7.60 (d, $J=4.0 \mathrm{~Hz}, 2 \mathrm{H}, \operatorname{ArH}), 7.23$ (m, 4H, ArH), 7.11 (d, $J=$ $4.0 \mathrm{~Hz}, 2 \mathrm{H}, \mathrm{ArH}), 5.60$ (d, $J=4.0 \mathrm{~Hz}, 2 \mathrm{H}, \mathrm{ArH}) \mathrm{ppm} ;{ }^{13} \mathrm{C} \mathrm{NMR}$ (100 MHz, DMSO-d 6 ): $\delta$ 46.2, 113.4, 121.7, 122.1, 122.8, 124.7, $129.4,129.6,129.7,129.8,130.3,130.9,131.4,132.4,132.7$, $132.9,133.2,136.5,136.6,137.4,139.5,141.5,142.3,151.9$, 155.0, 156.6, 156.7, 190.1 ppm. Anal. calcd for $\mathrm{C}_{39} \mathrm{H}_{20} \mathrm{ClN}_{3} \mathrm{O}_{2}$ : C, 78.33; H, 3.37; N, 7.03. Found: C, 78.28; H, 3.33; N, 6.96.

4.6.3 5-(4-Hydroxyphenyl)-10H-spiro[diindeno[1,2-b:2' $\left.\mathbf{2}^{\prime}, \mathbf{1}^{\prime}-e\right]$ pyridine-11,11'-indeno[1,2-b]quinoxaline $]-10,12(5 H)$-dione $(5 c)$. Dark red solid, Rf ( $n$-hexane : ethylacetate): $7: 3(\mathrm{v} / \mathrm{v})=0.51$; mp: $251{ }^{\circ} \mathrm{C}$. IR (KBr) $\nu: 3431,3041,2938,1728,1568,1382,1335$, $1198 \mathrm{~cm}^{-1}$; ${ }^{1} \mathrm{H}$ NMR (400 MHz, DMSO-d 6 ) $\delta: 8.18$ (s, 1H, ArH), 8.15 (s, 1H, ArH), 8.14 (s, 1H, ArH), 8.12 (s, J=8.0 Hz, 1H, ArH), 8.07 (s, 1H, ArH), 7.91 (s, 1H, ArH), 7.89 (s, 1H, ArH), 7.86 (s, 3H, ArH), 7.72 (s, 1H, ArH), 7.70 (s, 1H, ArH), 7.68 (s, 1H, ArH), 7.30 (s, 1H, ArH), $7.29(\mathrm{~s}, 1 \mathrm{H}, \operatorname{ArH}), 7.25(\mathrm{~s}, 1 \mathrm{H}, \operatorname{ArH}), 7.21(\mathrm{~s}, 1 \mathrm{H}$, ArH), 7.08 (s, 1H, OH), 5.71 (d, $J=4.0 \mathrm{~Hz}, 2 \mathrm{H}, \mathrm{ArH}) \mathrm{ppm}$. Anal. calcd for $\mathrm{C}_{39} \mathrm{H}_{21} \mathrm{~N}_{3} \mathrm{O}_{3}$ : C, 80.82; H, 3.65; N, 7.25. Found: C, 80.75; $\mathrm{H}, 3.60 ; \mathrm{N}, 7.19$.

4.6.4 5-(4-Chlorophenyl)-10H-spiro[diindeno[1,2-b:2' $\left.\mathbf{2}^{\prime} \mathbf{1}^{\prime}-e\right]$ pyridine-11,11'-indeno[1,2-b]quinoxaline $]-10,12(5 H)$-dione (5d). Dark red solid, $\mathrm{Rf}(n$-hexane : ethylacetate): $7: 3(\mathrm{v} / \mathrm{v})=0.63 ; \mathrm{mp}$ $289^{\circ} \mathrm{C}$. IR (KBr) $\nu$ : 3431, 3042, 2923, 1728, 1569, 1383, 1337, $1197 \mathrm{~cm}^{-1}$; ${ }^{1} \mathrm{H}$ NMR (400 MHz, DMSO-d $) \delta:{ }^{1} \mathrm{H}$ NMR $(400 \mathrm{MHz}$, DMSO-d $\left.\mathrm{d}_{6}\right): \delta(\mathrm{ppm}) 8.18(\mathrm{~s}, 1 \mathrm{H}, \operatorname{ArH}), 8.15(\mathrm{~s}, 1 \mathrm{H}, \operatorname{ArH}), 8.14(\mathrm{~s}$, $1 \mathrm{H}, \mathrm{ArH}), 8.12$ (s, 1H, ArH), 8.09 (s, 2H, ArH), 7.95 (s, 1H, ArH), 7.89 (s, 3H, ArH), 7.87 (s, 2H, ArH), 7.70 (t, $J=8.0 \mathrm{~Hz}, 2 \mathrm{H}, \operatorname{ArH})$, 7.22 (s, 1H, ArH), 7.20 (s, 1H, ArH), 7.10 (d, J=4.0 Hz, 3H, ArH), $5.65(\mathrm{~d}, J=4.0 \mathrm{~Hz}, 2 \mathrm{H}, \mathrm{ArH}) \mathrm{ppm}$. Anal. calcd for $\mathrm{C}_{39} \mathrm{H}_{20} \mathrm{ClN}_{3} \mathrm{O}_{2}$ : C, 78.33; H, 3.37; N, 7.03. Found: C, 78.26; H, 3.30; N, 6.98.

4.6.5 5-(3-Nitrophenyl)-10H-spiro[diindeno[1,2-b:2', $\left.\mathbf{1}^{\prime}-e\right]$ pyridine-11,11'-indeno[ $[1,2-b]$ quinoxaline $]-10,12(5 H)$-dione $(5 e)$. Dark red solid, $\operatorname{Rf}(n$-hexane : ethylacetate): $7: 3(\mathrm{v} / \mathrm{v})=0.58 ; \mathrm{mp}$ $181{ }^{\circ} \mathrm{C}$. IR (KBr) $\nu: 3439,3067,2911,1701,1535,1383,1343$, $1000 \mathrm{~cm}^{-1} ;{ }^{1} \mathrm{H}$ NMR (400 MHz, DMSO-d $\left.{ }_{6}\right) \delta: 8.24(\mathrm{~d}, J=8.0 \mathrm{~Hz}$, $2 \mathrm{H}, \operatorname{ArH}), 8.18$ (d, $J=8.0 \mathrm{~Hz}, 1 \mathrm{H}, \operatorname{ArH}), 8.11(\mathrm{~m}, 3 \mathrm{H}, \operatorname{ArH}), 7.88$ $(\mathrm{m}, 3 \mathrm{H}, \mathrm{ArH}), 7.63$ (t, $J=8.0 \mathrm{~Hz}, 3 \mathrm{H}, \mathrm{ArH}), 7.24(\mathrm{~d}, J=8.0 \mathrm{~Hz}$, 2H, ArH), 7.14 (m, 4H, ArH), 5.97 (d, $J=8.0 \mathrm{~Hz}, 2 \mathrm{H}, \mathrm{ArH}) \mathrm{ppm}$. Anal. calcd for $\mathrm{C}_{39} \mathrm{H}_{20} \mathrm{~N}_{4} \mathrm{O}_{5}: \mathrm{C}, 75.00 ; \mathrm{H}, 3.23 ; \mathrm{N}, 8.97$. Found: $\mathrm{C}$, 74.95; H, 3.18; N, 8.91.
4.6.6 5-(2-Chlorophenyl)-10H-spiro[diindeno[1,2-b:2' $\left.\mathbf{2}^{\prime} \mathbf{1}^{\prime}-e\right]$ pyridine-11,11'-indeno[ $[1,2-b]$ quinoxaline $]-10,12(5 H)$-dione $(5 f)$. Dark red solid, $\operatorname{Rf}(n$-hexane : ethylacetate) $7: 3(\mathrm{v} / \mathrm{v})=0.62 ; \mathrm{mp}$ $281^{\circ} \mathrm{C}$. IR (KBr) $\nu: 3435,3061,2922,1703,1578,1386,1337$, $1003 \mathrm{~cm}^{-1} ;{ }^{1} \mathrm{H}$ NMR (400 MHz, DMSO-d 6 ) $\delta: 8.19$ (m, 1H, ArH), $8.15(\mathrm{~m}, 1 \mathrm{H}, \mathrm{ArH}), 8.06$ (m, 1H, ArH), 8.02 (m, 1H, ArH), $7.94(\mathrm{~m}$, 1H, ArH), 7.87 (m, 3H, ArH), 7.78 (m, 2H, ArH), $7.73(\mathrm{~m}, 1 \mathrm{H}$, ArH), 7.62 (m, 1H, ArH), 7.54 (m, 1H, ArH), 7.27 (m, 1H, ArH), 7.18 (m, 1H, ArH), 7.12 (m, 1H, ArH), 7.05 (m, 1H, ArH), 6.94 (m, $1 \mathrm{H}, \operatorname{ArH}), 5.59$ (d, $J=4.0 \mathrm{~Hz}, 2 \mathrm{H}, \mathrm{ArH}) \mathrm{ppm}$. Anal. calcd for $\mathrm{C}_{39} \mathrm{H}_{20} \mathrm{ClN}_{3} \mathrm{O}_{2}$ : C, 78.33; H, 3.37; N, 7.03. Found: C, 78.27; H, 3.29; N, 6.98.

4.6.7 5-Phenyl-10H-spiro[diindeno[1,2-b:2 $\left.2^{\prime}, 1^{\prime}-e\right]$ pyridine$11,11^{\prime}$-indeno[1,2-b]quinoxaline $]-10,12(5 H)$-dione $(5 \mathrm{~g})$. Dark red solid, Rf ( $n$-hexane : ethylacetate): $7: 3(\mathrm{v} / \mathrm{v})=0.64 ;$ (mprep 277 $\left.{ }^{\circ} \mathrm{C}\right) /\left(\mathrm{mp}_{\text {lit }}>280{ }^{\circ} \mathrm{C}\right) .{ }^{6} \mathrm{IR}(\mathrm{KBr}) \nu: 3430,3062,2910,1696,1579$, 1385, 1336, $999 \mathrm{~cm}^{-1}$; ${ }^{1} \mathrm{H}$ NMR (400 MHz, DMSO-d $\left.{ }_{6}\right) \delta: 8.88(\mathrm{~m}$, $3 \mathrm{H}, \mathrm{ArH}), 8.05(\mathrm{~m}, 3 \mathrm{H}, \mathrm{ArH}), 7.92(\mathrm{~m}, 2 \mathrm{H}, \mathrm{ArH}), 7.83(\mathrm{~m}, 3 \mathrm{H}$, ArH), 7.62 (m, 2H, ArH), 7.23 (m, 2H, ArH), 7.10 (m, 4H, ArH), $5.59(\mathrm{~d}, J=8.0 \mathrm{~Hz}, 2 \mathrm{H}, \mathrm{ArH}) \mathrm{ppm}$. Anal. calcd for $\mathrm{C}_{39} \mathrm{H}_{21} \mathrm{~N}_{3} \mathrm{O}_{2}: \mathrm{C}$, 83.11; H, 3.76; N, 7.46. Found: C, 83.07; H, 3.69; N, 7.38.

4.6.8 5-(o-Tolyl)-10H-spiro[diindeno $\left[1,2-b: 2^{\prime}, 1^{\prime}-e\right]$ pyridine11,11'-indeno[1,2-b]quinoxaline]-10,12(5H)-dione (5h). Dark red solid, Rf ( $n$-hexane : ethylacetate): $7: 3(\mathrm{v} / \mathrm{v})=0.61 ; \mathrm{mp}$ $201{ }^{\circ} \mathrm{C}$. IR (KBr) $\nu$ : 3438, 3061, 2927, 1697, 1578, 1386, 1337, $1000 \mathrm{~cm}^{-1} ;{ }^{1} \mathrm{H}$ NMR (400 MHz, DMSO-d 6 ) $\delta: 8.21(\mathrm{~m}, 2 \mathrm{H}, \mathrm{ArH})$, $8.19(\mathrm{~m}, 1 \mathrm{H}, \mathrm{ArH}), 8.02(\mathrm{~m}, 2 \mathrm{H}, \mathrm{ArH}), 7.86(\mathrm{~m}, 2 \mathrm{H}, \mathrm{ArH}), 7.83(\mathrm{~m}$, 2H, ArH), 7.77 (m, 2H, ArH), 7.67 (m, 1H, ArH), $7.23(\mathrm{~m}, 1 \mathrm{H}$, ArH), 7.21 (m, 1H, ArH), 7.15 (m, 1H, ArH), 7.12 (m, 1H, ArH), $6.96(\mathrm{~m}, 1 \mathrm{H}, \mathrm{ArH}), 6.88(\mathrm{~m}, 1 \mathrm{H}, \operatorname{ArH}), 5.55(\mathrm{~d}, J=8.0 \mathrm{~Hz}, 2 \mathrm{H}$, ArH), 1.21 (s, 3H, $\mathrm{CH}_{3}$ ) ppm; ${ }^{13} \mathrm{C}$ NMR (100 MHz, DMSO-d 6 ) $\delta$ : 17.7, 46.4, 121.9, 122.1, 122.8, 124.7, 128.6, 129.1, 129.5, 129.8, $130.3,130.8,130.0,131.4,132.1,132.4,132.9,133.2,133.3$, 136.4, 136.8, 137.1, 137.4, 138.2, 141.5, 142.6, 151.9, 154.9, 156.8, 156.2, 190.1 ppm. Anal. calcd for $\mathrm{C}_{40} \mathrm{H}_{23} \mathrm{~N}_{3} \mathrm{O}_{2}$ : C, 83.17; H, 4.01; N, 7.27. Found: C, 83.11; H, 3.96; N, 7.17.

4.6.9 5-(2,4-Dimethylphenyl)-10H-spiro[diindeno[1,2$b: 2^{\prime}, 1^{\prime}$-e $]$ pyridine-11,11'-indeno[1,2- $\left.b\right]$ quinoxaline $]-10,12(5 H)$ dione (5i). Dark red solid, $\operatorname{Rf}(n$-hexane : ethylacetate): $7: 3(\mathrm{v} / \mathrm{v})$ $=0.58 ; \mathrm{mp} 234{ }^{\circ} \mathrm{C}$. IR (KBr) $\nu: 3428,3062,2923,1702,1573$, 1385, 1337, $999 \mathrm{~cm}^{-1} ;{ }^{1} \mathrm{H}$ NMR (400 MHz, DMSO-d 6 ) $\delta: 8.18$ (d, $J$ $=8.0 \mathrm{~Hz}, 1 \mathrm{H}, \operatorname{ArH}), 8.15(\mathrm{~s}, 1 \mathrm{H}, \operatorname{ArH}), 8.13(\mathrm{~s}, 2 \mathrm{H}, \operatorname{ArH}), 8.01(\mathrm{~d}, J$ $=8.0 \mathrm{~Hz}, 1 \mathrm{H}, \operatorname{ArH}), 7.92(\mathrm{~s}, 2 \mathrm{H}, \operatorname{ArH}), 7.89(\mathrm{~d}, J=8.0 \mathrm{~Hz}, 2 \mathrm{H}$, $\operatorname{ArH}), 7.73$ (d, J=8.0 Hz, 2H, ArH), 7.61 (s, 1H, ArH), 7.52 (s, 1H, $\operatorname{ArH}), 7.46$ (d, $J=8.0 \mathrm{~Hz}, 1 \mathrm{H}, \operatorname{ArH}), 7.22$ (d, $J=8.0 \mathrm{~Hz}, 2 \mathrm{H}, \operatorname{ArH})$, $7.16(\mathrm{~d}, J=8.0 \mathrm{~Hz}, 1 \mathrm{H}, \operatorname{ArH}), 7.08$ (s, 2H, ArH), 5.63 (d, $J=$ $4.0 \mathrm{~Hz}, 2 \mathrm{H}, \mathrm{ArH}), 2.56$ (s, 3H, $\left.\mathrm{CH}_{3}\right), 2.38$ (s, 3H, $\left.\mathrm{CH}_{3}\right)$ ppm. Anal. calcd for $\mathrm{C}_{41} \mathrm{H}_{25} \mathrm{~N}_{3} \mathrm{O}_{2}$ : C, 83.23; H, 4.26; N, 7.10. Found: C, 83.18; $\mathrm{H}, 4.19 ; \mathrm{N}, 7.01$.

4.6.10 5-(4-Methylphenyl)-10H-spiro[diindeno[1,2-b:2' $\left.\mathbf{2}^{\prime}, \mathbf{1}^{\prime}-e\right]$ pyridine-11,11'-indeno[1,2- $b]$ quinoxaline $]$-10,12(5H)-dione (5j). Dark red solid, Rf ( $n$-hexane : ethylacetate): $7: 3(\mathrm{v} / \mathrm{v})=0.64$; (mprep. $\left.197^{\circ} \mathrm{C}\right) /\left(\mathrm{mp}_{\text {lit }} 193-205^{\circ} \mathrm{C}\right) .{ }^{6} \mathrm{IR}(\mathrm{KBr}) \nu: 3432,3061,2923$, 1697, 1577, 1386, 1337, $997 \mathrm{~cm}^{-1} ;{ }^{1} \mathrm{H}$ NMR (400 MHz, DMSO-d 6 ) $\delta: 8.24$ (s, 1H, ArH), 8.19 (d, $J=8.0 \mathrm{~Hz}, 1 \mathrm{H}, \operatorname{ArH}), 8.13(\mathrm{~s}, 1 \mathrm{H}$, ArH), 8.05 (d, $J=8.0 \mathrm{~Hz}, 3 \mathrm{H}, \operatorname{ArH}), 7.92$ (d, $J=8.0 \mathrm{~Hz}, 1 \mathrm{H}, \operatorname{ArH})$, 
$7.87(\mathrm{t}, J=4.0 \mathrm{~Hz}, 2 \mathrm{H}, \operatorname{ArH}), 7.79(\mathrm{~d}, J=8.0 \mathrm{~Hz}, 1 \mathrm{H}, \operatorname{ArH}), 7.73(\mathrm{~d}$, $J=8.0 \mathrm{~Hz}, 2 \mathrm{H}, \mathrm{ArH}), 7.60$ (d, $J=4.0 \mathrm{~Hz}, 2 \mathrm{H}, \operatorname{ArH}), 7.24(\mathrm{~s}, 1 \mathrm{H}$, $\operatorname{ArH}), 7.22$ (d, $J=8.0 \mathrm{~Hz}, 1 \mathrm{H}, \operatorname{ArH}), 7.16$ (t, $J=8.0 \mathrm{~Hz}, 1 \mathrm{H}, \operatorname{ArH})$, 7.09 (d, $J=4.0 \mathrm{~Hz}, 1 \mathrm{H}, \operatorname{ArH}), 5.97$ (d, $J=8.0 \mathrm{~Hz}, 2 \mathrm{H}, \operatorname{ArH}), 1.22$ (s, $3 \mathrm{H}, \mathrm{CH}_{3}$ ) ppm; Anal. calcd for $\mathrm{C}_{40} \mathrm{H}_{23} \mathrm{~N}_{3} \mathrm{O}_{2}: \mathrm{C}, 83.17 ; \mathrm{H}$, 4.01; N, 7.27. Found: C, 83.09; H, 3.93; N, 7.18.

4.6.11 5-(4-Nitrophenyl)-10H-spiro[diindeno[1,2-b:2', $\left.\mathbf{1}^{\prime}-e\right]$ pyridine-11,11'-indeno[1,2-b]quinoxaline $]-10,12(5 H)$-dione $(5 \mathrm{k})$. Dark red solid, Rf ( $n$-hexane : ethylacetate): $7: 3(\mathrm{v} / \mathrm{v})=0.56$; $\left(\mathrm{mp}_{\text {rep }} \cdot 178^{\circ} \mathrm{C}\right) /\left(\mathrm{mp}_{\text {lit }} 175-180{ }^{\circ} \mathrm{C}\right) .{ }^{6} \mathrm{IR}(\mathrm{KBr}) \nu: 3431,3065,2923$, 1705, 1578, 1339, 1308, $1001 \mathrm{~cm}^{-1}$; ${ }^{1} \mathrm{H}$ NMR (400 MHz, DMSO$\left.\mathrm{d}_{6}\right) \delta: 8.24(\mathrm{~m}, 1 \mathrm{H}, \operatorname{ArH}), 8.22(\mathrm{~m}, 1 \mathrm{H}, \operatorname{ArH}), 8.18(\mathrm{~m}, 1 \mathrm{H}, \operatorname{ArH})$, 8.09 (m, 2H, ArH), 7.93 (m, 2H, ArH), 7.89 (m, 1H, ArH), 7.77 (m, 1H, ArH), 7.75 (m, 1H, ArH), $7.32(\mathrm{~m}, 2 \mathrm{H}, \operatorname{ArH}), 7.23(\mathrm{~m}, 1 \mathrm{H}$, ArH), 7.11 (m, 1H, ArH), 5.63 (d, $J=8.0 \mathrm{~Hz}, 1 \mathrm{H}, \mathrm{ArH}) \mathrm{ppm}$; Anal. calcd for $\mathrm{C}_{39} \mathrm{H}_{20} \mathrm{~N}_{4} \mathrm{O}_{4}$ : C, 76.97; H, 3.31; N, 9.21. Found: C, 76.90; $\mathrm{H}, 3.27$; N, 9.15 .

\section{Conflicts of interest}

There are no conflicts to declare.

\section{Acknowledgements}

The authors are grateful to the University of Kashan for supporting this work by grant no. 159148/77.

\section{Notes and references}

1 B. M. Trost and M. K. Brennan, Asymmetric Syntheses of Oxindole and Indole Spirocyclic Alkaloid Natural Products, Synthesis, 2009, 18, 3003-3025.

2 S. J. Kalita, B. Das, D. C. Deka and A. Quick, Simple and Clean Synthesis of Spiro(indoline-3, $4^{\prime}$-pyrazolo $\left[4^{\prime}, 3^{\prime}: 5,6\right]$ pyrido[2,3-d]pyrimidines) in Water through a Novel OnePot Multicomponent Reaction, ChemistrySelect, 2017, 2, 5701-5706.

3 M. Salehpoura, J. Aziziana and H. Kefayati, Clean synthesis of novel spiro[indene-2,2'-[1,3,5]-oxathiazine]-1,3-diones in water, Chin. Chem. Lett., 2017, 28, 1079-1082.

4 M. R. Poor Heravi and F. Norouzy, One-pot, four-component synthesis of novel biologically important indeno[2,3-b] quinoxaline]-3-carbonitriles in fluoro-alcohols under ultrasound irradiation, Res. Chem. Intermed., 2017, 43, 4265-4282.

5 S. M. Colegate, N. Anderton, J. Edgar, C. A. Bourke and R. N. Oram, Suspected blue canary grass (Phalaris coerulescens) poisoning of horses, Aust. Vet. J., 1999, 77(8), 537-538.

6 T. Amanpour, A. Bazgir, A. M. Ardekani and R. Ghahremanzadeh, Pseudo five-component synthesis of 5-phenyldihydrospiro

[diindenopyridineindenoquinoxaline] dione derivatives via a one-pot condensation reaction, Monatsh. Chem., 2014, 145, 627-632.

7 K. S. Mani, W. Kaminsky and S. P. Rajendran, A facile atom economic one pot multicomponent synthesis of bioactive spiroindenoquinoxaline pyrrolizines as potent antioxidant and anti cancer agents, New J. Chem., 2018, 42(1), 301-310.

8 A. Corma, H. Garcia and F. X. L. I. Xamena, Engineering Metal Organic Frameworks for Heterogeneous Catalysis, Chem. Rev., 2010, 110, 4606-4655.

9 A. Baiker, Supercritical Fluids in Heterogeneous Catalysis, Chem. Rev., 1998, 99, 453-474.

10 W. C. Conner and J. L. Falconer, Spillover in Heterogeneous Catalysis, Chem. Rev., 1995, 95, 759-788.

11 K. V. S. Ranganath and F. Glorius, Superparamagnetic nanoparticles for asymmetric catalysis a perfect match, Catal. Sci. Technol., 2011, 1, 13-22.

12 A.-H. Lu, E. L. Salabas and F. Schüth, Magnetic Nanoparticles: Synthesis, Protection, Functionalization, and Application, Angew. Chem., Int. Ed., 2007, 46, 1222-1244.

13 A. Maleki, M. Aghaei and N. Ghamari, Synthesis of Benzimidazolo[2,3-b]quinazolinone Derivatives via a Onepot Multicomponent Reaction Promoted by a Chitosanbased Composite Magnetic Nanocatalyst, Chem. Lett., 2015, 44, 259-261.

14 C. Yuwei and W. Jianlong, Preparation and characterization of magnetic chitosan nanoparticles and its application for Cu(II) removal, Chem. Eng. J., 2011, 168, 286-292.

15 G.-Y. Li, Y.-R. Jiang, K.-L. Huang, P. Ding and J. Chen, Preparation and properties of magnetic $\mathrm{Fe}_{3} \mathrm{O}_{4}$-chitosan nanoparticles, J. Alloys Compd., 2008, 466, 451-456.

16 H. Wang, J. Wang, J. Wang, R. Zhu, Y. Shen, Q. Xu and X. Hu, Spectroscopic method for the detection of 2,4dichlorophenoxyacetic acid based on its inhibitory effect towards catalase immobilized on reusable magnetic $\mathrm{Fe}_{3} \mathrm{O}_{4}$ chitosan nanocomposite, Sens. Actuators, B, 2017, 247, 146-154.

17 A. Maleki, M. Aghaei and N. Ghamari, Facile synthesis of tetrahydrobenzoxanthenones via a one-pot threecomponent reaction using an eco-friendly and magnetized biopolymer chitosan-based heterogeneous nanocatalyst, Appl. Organomet. Chem., 2016, 30, 939-942.

18 K. Balamurugan, S. Perumal and J. Carlos Menendez, New four-component reactions in water: a convergent approach to the metal-free synthesis of spiro[indoline/ acenaphthylene-3,4'-pyrazolo[3,4-b]pyridine] derivatives, Tetrahedron, 2011, 67, 3201-3208.

19 V. Polshettiwar and R. S. Varma, Aqueous microwave chemistry: a clean and green synthetic tool for rapid drug discovery, Chem. Soc. Rev., 2008, 37, 1546-1557.

20 B. Ganem, Strategies for Innovation in Multicomponent Reaction Design, Acc. Chem. Res., 2009, 42, 463-472.

21 A. Padwa, Domino reactions of rhodium(II) carbenoids for alkaloid synthesis, Chem. Soc. Rev., 2009, 38, 3072-3081.

22 M. Rueping, J. Dufour and M. S. Maji, Relay catalysis: combined metal catalyzed oxidation and asymmetric iminium catalysis for the synthesis of $\mathrm{Bi}$ - and tricyclic chromenes, Chem. Commun., 2010, 46, 2447-2449.

23 R. Liangce, H. Hongxia, J. Hong and T. Shujiang, Efficient and Facile Synthesis of 3-Amino-1-aryl-9H-fluorene-2,4dicarbo nitrile Under Solvent-Free Conditions, Synth. Commun., 2009, 39(19), 3493-3499. 
24 S. Das, Recent applications of ninhydrin in multicomponent reactions, $R S C A d v ., 2020,10,18875-18906$.

$25 \mathrm{H}$. Naeimi and L. Moradi, Facile, convenient and regioselective direct ortho-acylation of phenols and naphthols catalyzed by Lewis acids under free solvent and microwave conditions, J. Mol. Catal. A: Chem., 2006, 256, 242-246.

26 H. Naeimi, F. Salimi and K. Rabiei, Mild and convenient one pot synthesis of Schiff bases in the presence of $\mathrm{P}_{2} \mathrm{O}_{5} / \mathrm{Al}_{2} \mathrm{O}_{3}$ as new catalyst under solvent-free conditions, J. Mol. Catal. A: Chem., 2006, 260, 100-104. 